Original Research

\title{
Summary Guidance for Daily Practices on Glycemic Control and Foot Care Behavior
}

\section{Devi Mediarti', Rosnani Rosnani' ${ }^{1}$, and Hidayat Arifin²}

${ }^{1}$ Poltekkes Kemenkes Palembang, South Sumatera, Indonesia

${ }^{2}$ Faculty of Nursing, Universitas Airlangga, Surabaya, Indonesia

\begin{abstract}
Introduction: The Prevalence of Diabetes Foot Ulcers (DFU) in Indonesia is increasing every year. Summary Guidance for Daily Practice (SGFDP) is a media used to discuss and share knowledge to prevent foot ulcer in patients with Type 2 Diabetes Mellitus (T2DM). The aim was to know the influence of applying SGFDP on glycemic control (fasting blood glucose levels) and foot care behavior.

Methods: The study was quasi-experimental utilizing a pretest-post-test with a control group design. The sample obtained was 232 respondents through consecutive sampling. The variables were SGFDP, glycemic control, and foot care behavior. The intervention was conducted for three weeks meeting. The data collected using observation sheets and the Nottingham Assessment of Functional Footcare (NAFF) questionnaire. The results were analyzed using the Wilcoxon and Mann-Whitney tests.

Results: Most of respondents were elderly aged 41-50 years old. Respondents showed significant progressed of foot care behavior on before and after treatment. The results showed a significant influence from SGFDP on foot care behavior $(\mathrm{p}=0.001)$.

Conclusion: The application of SGFDP as an approach to prevent foot ulcers among adults T2DM was significantly affected. It was conducted by discussing and sharing knowledge and utilizing a foot ulcer prevention simulation with foot exercises. Sharing information and the attention given by the nurses in the form of regular meetings can increase patient knowledge and induce behavior changes among adult T2DM.
\end{abstract}

\section{ARTICLE HISTORY}

Received: August 03, 2020

Accepted: August 10, 2020

\section{KEYWORDS}

diabetes foot care; diabetes mellitus; glycemic control; prevention

\section{CONTACT}

Devi Mediarti

$\triangle$ devi.mediarti@gmail.com

$\doteq$ Poltekkes Kemenkes Palembang, South Sumatera, Indonesia

Cite this as: Mediarti, D., Rosnani, R., \& Arifin, H. (2020). Summary Guidance for Daily Practices on Glycemic Control and Foot Care Behavior. Jurnal Ners, 15(2). 142-147. doi:http://dx.doi.org/10.20473/in.v15i2.21127

\section{INTRODUCTION}

Diabetes mellitus (T2DM) is a metabolic disease characterized by an increase in blood sugar levels. This occurs due to abnormalities in insulin secretion, insulin action or both (Kusnanto, 2017). T2DM is one of the most chronic diseases experienced by people in the world. T2DM patients are susceptible to nerve and vascular damage which can result in a loss of the protective sensation in the legs, poor circulation, biomechanical changes in leg and skin trauma (Fan, 2012). If it is not treated well, it can occur because the development of ulcers is known in diabetic patients to be preceded by a history of trauma (neuropathy) or vasculopathy (Schaper et al., 2017). T2DM-related complications are a major cause of morbidity and mortality, and they have a serious impact on the quality of life of the patients (Hsieh et al., 2016). Foot ulceration and subsequent lower limb amputation are common and serious chronic complications for T2DM patients (Fan, 2012).

It is estimated that in 2035 , the global prevalence of T2DM will increase to nearly 600 million (Shearman \& Rawashdeh, 2016). In Indonesia, T2DM patients are known to have increased from $1.1 \%$ in 2007 to 2.1 percent in 2013. The province of East Java, with the prevalence of T2DM based on a doctor's diagnosis and symptoms, is $1.2 \%$ and $1.6 \%$ respectively (Badan Penelitian dan Pengembangan Kesehatan, 2013).The four main objectives of service providers include health promotion, disease prevention, patient care and meeting the patient's needs. The management of T2DM patients in the physical aspect with early education is about T2DM, the monitoring of routine blood sugar levels, diet, how to use the health facilities, physical exercise and 
the importance of foot care (PERKENI, 2015). The role of the nurses is to prevent the risk of ulcers related to T2DM through education, demonstration and monitoring about foot care.

SGFDP is a summary of suggested guidelines for daily practice summarizing the essence of the prevention and management of foot problems in T2DM patients. SGFDP as part of a more complete guide on foot care consisting of the identification of risky feet, the inspection and routine checking of feet at risk, health education for patients regarding foot care, routine footwear care and identification and the handling of pre-ulcer signs (Schaper et al., 2017). SGFDP is provided more complete in health education and activity. Due to the important of SGFDP among T2DM to manage DM, thus we encouraged to determine the influence of applying SGFDP on glycemic control and foot care behavior.

\section{MATERIALS AND METHODS}

\section{Research design, population, sample, and variables}

The design was quasi-experimental with a pre-posttest control group design. The population in this research consisted of all outpatients with T2DM in three Primary Health Services (HPS). The researcher used two HPS for treatment group and one HPS for control group because the population is bigger, and the area coverage is wider. The samples obtained 232 respondents (116 in the treatment group and 116 in the control group) with consecutive sampling technique. This research was conducted at Palembang in South Sumatera from October 9 to December 20, 2018. The inclusion criteria in this research were 1) low risk T2DM patients, 2) T2DM history of more than 10 years, 3) can communicate verbally well, and they are able to read and write and 4) taking T2DM therapy in the form of oral subcutaneous therapy. The exclusion criteria were 1) patients with T2DM who experienced cognitive impairment and 2) T2DM patients with foot ulcers. The independent variable was the application of SGFDP and the dependent variables were glycemic control and foot care behavior.

\section{Instruments}

SGFDP used the modules as form of media to give to the respondents. The module of SGFDP consists of information about T2DM, diet, the behavior of people with T2DM, foot care behavior with exercise and psychosocial education to reduce stress in T2DM patients. The instrument of glycemic control was an observation sheet. Glycemic control used peripheral blood and measured by Easy Touch 3in 1 Glucose, Uric Acid and Cholesterol. Foot care behavior was measured using the Nottingham Assessment of Functional Footcare (NAFF) questionnaire by Lincoln, et. al. (Lincoln et al., 2008), which was modified by Putri, at. al. (Putri et al., 2013) and translated into the Indonesian language. The number of questions totaled 27 using a Likert scale with a score of $0-3$. We obtained a range of scores from 0 to 81; the higher the score, the better the T2DM foot care behavior. This questionnaire was tested for validity and reliability with a Cronbach's alpha value of 0.720 .

\section{Research procedure and analysis}

This research was carried out in collaboration with the existing program activities in the primary health service in order to increase the knowledge of the T2DM patients through empowerment and health education. The research has passed the ethical review and obtained an Ethical Approval certificate No. 208/UN2.F12.D/HKP.02.04/2018 issued by the Health Research Ethics Committee of Faculty of Nursing Science, Universitas Indonesia. The research was conducted in the treatment group by providing SGFDP that formulated by researcher with select modules on three meetings over three weeks. The first week was to provide health education about T2DM and the screening of the respondents with the risk of foot ulcers. The second week was explained as the ideal diet and behavior of people with T2DM, and the third weeks was on teaching prevention of foot ulcers through a demonstration of foot exercises and monitoring. The control group was given information about T2DM through SGFDP modules. The data was analyzed using IBM SPSS Statistic 25 (SPSS, 2019). The statistical analysis used a Wilcoxon Signed Rank and Mann-Whitney $U$ test. The confidence interval was $95 \%$ with alpha $(\alpha)=0.05$.

\section{RESULTS}

The characteristics of the respondents in (Table 1) shows that the majority of the respondents in both groups were in the age group of the elderly and that the majority were female. The last level of education for both groups was high school and the majority of respondents in both groups did not work. The majority of the income in the control and treatment groups was $>2.6$ million. The majority of the respondents in the control group had had T2DM for 14-15 years and the treatment group had had T2DM for $10-13$ years.

The results of the analysis of fasting blood glucose in the control and treatment groups at the pre-test and post-test showed that all of the respondents had differences in the mean and std. deviation. The results of the data obtained using the Wilcoxon Signed Ranks test on fasting blood glucose in the pre-test and posttest of the control group showed no change in the results between the pre-test and post-test of the respondents. The test results showed $p>0.05$ which was 0.11 , which means that there was no significant difference. The treatment group showed $\mathrm{p}<0.05$ which was equal to 0.013 , which means that the pretest and post-test in the treatment group had significant differences. The results of the post-test carried out using the Mann-Whitney $U$ test on fasting blood glucose data in the control and treatment groups was 0.836 which equals $p>0.05$. It can be 
Table 1. Characteristics of The Respondents in The Control and Treatment Groups of Patients with T2DM (n=232)

\begin{tabular}{lcccc}
\hline \multicolumn{1}{c}{ Characteristic } & \multicolumn{2}{c}{ Control Group } & \multicolumn{2}{c}{ Treatment Group } \\
\cline { 2 - 5 } & $\mathbf{n}$ & $\mathbf{\%}$ & $\mathbf{n}$ & $\mathbf{\%}$ \\
\hline Age & & & & \\
$\quad$ Adult (30-40 year) & 16 & 13.8 & 27 & 23.3 \\
$\quad$ Elderly (41-50 year) & 100 & 86.2 & 89 & 76.7 \\
Sex & & & & \\
$\quad$ Male & 44 & 37.9 & 50 & 43.1 \\
$\quad$ Female & 72 & 62.1 & 66 & 56.9 \\
Education & & & & \\
$\quad$ Elementary School & 19 & 16.4 & 23 & 19.8 \\
$\quad$ Junior High School & 26 & 22.4 & 39 & 33.6 \\
$\quad$ Senior High School & 54 & 46.6 & 46 & 39.7 \\
$\quad$ University & 17 & 14.7 & 8 & 6.9 \\
Work & & & & \\
$\quad$ Does not work & 72 & 62.1 & 85 & 73.3 \\
$\quad$ Private & 26 & 22.4 & 23 & 19.8 \\
$\quad$ Government employees & 18 & 15.5 & 8 & 6.9 \\
Average income & & & & \\
$\quad<1.5$ million & 43 & 37.1 & 39 & 33.6 \\
1.5-2.5 million & 28 & 24.1 & 32 & 27.6 \\
$\quad>2.6$ million & 45 & 38.8 & 45 & 38.8 \\
Long suffer from T2DM & & & & \\
10-13 years & 49 & 42.2 & 83 & 71.6 \\
14-15 years & 67 & 57.8 & 33 & 28.4 \\
\hline
\end{tabular}

Table 2. Distribution of Blood Glucose and Foot Care Behavior in The Control and Treatment Groups of Patients T2DM $(n=232)$

\begin{tabular}{|c|c|c|c|c|}
\hline \multirow[b]{2}{*}{ Variables } & \multicolumn{2}{|c|}{ Control Group } & \multicolumn{2}{|c|}{ Treatment Group } \\
\hline & Pretest & Posttest & Pretest & Posttest \\
\hline \multicolumn{5}{|l|}{ Blood Glucose } \\
\hline Mean \pm SD & $121.47 \pm 29.153$ & $122.72 \pm 29.396$ & $117.29 \pm 8.344$ & $115.9 \pm 14.62$ \\
\hline p-value & \multicolumn{2}{|c|}{$0.11^{\mathrm{a}}$} & \multicolumn{2}{|c|}{$0.013^{\mathrm{a}}$} \\
\hline p-value & \multirow{2}{*}{\multicolumn{4}{|c|}{$0.836^{\mathrm{b}}$}} \\
\hline Foot Care Behavior & & & & \\
\hline Mean \pm SD & $38 \pm 7.489$ & $36.28 \pm 9.878$ & $43.02 \pm 7.889$ & $45.42 \pm 8.254$ \\
\hline$p$-value & \multirow{2}{*}{\multicolumn{2}{|c|}{$0.274^{\mathrm{a}}$}} & \multicolumn{2}{|c|}{$0.003^{\mathrm{a}}$} \\
\hline$p$-value & & 0.0 & & \\
\hline
\end{tabular}

concluded that there were no significant differences in the results of the post-test data in the control and treatment groups (Table 2).

The results of the foot care behavior analysis in the control and treatment groups in the pre-test and posttest showed that all of the respondents had differences in the mean and std. deviation. The results of the data obtained using the Wilcoxon Signed Ranks test on foot care behavior on pre-test and post-test of the control group showed no change in the results between the pre-test and post-test of the respondents. The test results showed $p>0.05$, which was 0.274 which means that there was no significant difference. The treatment group showed $p<0.05$, which was equal to 0.003 , which means that the pretest and post-test in the treatment group had significant differences. The results of the post-test foot care behavior data using the Mann-Whitney U Test in the control and treatment groups were 0.001 which means $\mathrm{p}<0.05$. It can be concluded that there were significant differences in the results of the posttest data between the control and treatment groups (Table 2).

\section{DISCUSSION}

The SGFDP approach explains the basic principles of the prevention of foot problems in T2DM patients (Schaper et al., 2017) and it seeks to prevent ulcers in patients at risk with T2DM by providing integrated and adequate foot care (S.A Bus, D.G. Armstrong, R.W. Van Deursen, J.E.A.Lewis, C.F Caravaggi, 2016). Prevention bases SGFDP include risky feet identification, risky inspection and routine foot checks, patient health education about foot care, appropriate footwear care and the identification of pre-ulcerative signs. 
One risk factor of T2DM was age, especially for those older than 40 years. This is because at that age, there is an increase in glucose intolerance (Chai et al., 2018). In old age, bodily functions are physiologically decreasing because the aging process causes a decrease in insulin secretion or resistance. Therefore, the body's ability to control high blood glucose is not optimal. The aging process causes a decrease in insulin secretion or resistance, resulting in a macroangiopathy, which can affect the decrease in blood circulation, one of which is in the large or medium blood vessels in the legs.

Gender is one of the factors associated with the occurrence of T2DM, where women who have experienced menopause tend to be more insensitive to insulin. Diabetes in general, for men, comes faster than it does for women. Women can be protected from diabetes until they reach menopause because of the influence of the female hormone estrogen, which is a reproductive hormone that helps to regulate blood sugar levels in the body. The results of a study conducted by Martis, R et. al. (Martis et al., 2018) showed a higher prevalence of the incidence rate of T2DM in women than in men. Women are more at risk of developing diabetes because physically, women have a greater chance of increasing their body mass index. Post-menopausal monthly cycle (premenstrual syndrome) syndrome makes the distribution of body fat more easily accumulated due to the hormonal processes, so therefore women are more at risk of developing T2DM (Hsieh et al., 2016).

Education level has an important role in increasing the knowledge of T2DM. The majority of the residents did not know about T2DM. Knowledge can have an important role in the prevention of T2DM in the community. Education can influence a person, including a person's behavior and lifestyle, especially in reference to motivating people to participate in developments. In general, the higher the education level of someone, the easier it is for them to receive information (Wawan \& Dewi, 2014).

The respondents who suffered from T2DM needed to do more physical activities. In T2DM, exercise plays a major role in regulating blood glucose levels. Muscle contractions have properties such as the production insulin and increasing the permeability of the membrane to glucose in the contracting muscle (Bakar et al., 2017). At the time of exercise, insulin resistance is reduced, whereas insulin sensitivity increases when inactive. This is not a permanent effect. Therefore, exercise must be carried out continuously. Physical activity can be in the form of diabetic foot exercises. Exercise is very beneficial for improving blood circulation, losing weight and improving insulin sensitivity as it will improve the glucose levels in the blood.

Hyperinsulinemia (10fEU/ml) can cause atherosclerosis, which has an impact on vasculopathy which makes the legs prone to T2DM ulcers (Rachmawati et al., 2015). In addition, it is often accompanied by an increase in triglyceride and plasma cholesterol levels which will result in poor blood circulation to the tissue, which appears in the decrease of the dorsalis pedis artery pulse $(<60 \mathrm{x} / \mathrm{m})$ and decreased ankle brachial index $(<0.9)$, resulting in ulcers that usually start from the tip of the leg (Waspadji, 2006). All of the respondents in this study had suffered from T2DM for more than 10 years. Foot ulcers are especially common in T2DM patients who have suffered with the disease for 10 years or more. If their uncontrolled blood sugar levels are not seen to, then this will result in vasculopathy and neuropathy.

Physical activity is included in this research in the form of T2DM foot exercises. Physical activity increased the sensitivity of the insulin receptors in the active muscles (Albargawi et al., 2017). The main problem that occurs in T2DM is the occurrence of insulin resistance which causes glucose to not enter the cells. When a person engages in physical activity, there will be a muscle contraction which will eventually make it easier for glucose to enter the cell (Jankowska-Polaska et al., 2015). This means that when a person is engaged in physical activity, it will reduce the level of insulin resistance and this will eventually reduce their blood sugar levels. There are other factors that influence blood sugar levels. In addition to SGFDP implementation, there are several things that cause one's blood sugar to rise, namely a lack of exercise, an increased amount of food consumed, increased stress and emotional factors, weight gain and age, and the impact of treatment from drugs, such as steroids (Iljaž et al., 2017).

The driving factor was the factor obtained from the closest person to the patient and the social support given to the individual, such as their family, friends and teachers, and especially in this case, the health workers who can strengthen the behavior of SGFDP management. With the support provided by the closest people to them, it is expected to encourage behavior change in the patients (Nursalam, 2016). In terms of the prevention of injury in T2DM patients, foot care behavior is carried out in accordance with SGFDP, which consists of the identification of risky feet, the inspection and routine examination of risky feet, health education for patients about foot care, routine foot care and the identification of pre-ulcer signs in T2DM patients (Yamin et al., 2018).

The level of education of a person is very influential on any changes in attitude and behavior related to healthy living. Higher levels of education will make it easier for a person or community to absorb information and to implement it in their daily behavior patterns and lifestyle, especially in terms of health. Based on the information obtained by the researchers through questioning the respondents, the respondents said they always tried to maintain good foot care behavior in accordance with the principles of SGFDP so then further foot injuries can be prevented.

This is because of the intervention given by the researchers in the form of SGFDP through daily practice guidance that explain the basic principles of the prevention of foot problems in T2DM patients to prevent ulcers in patients at risk who have T2DM. 
Foot problems in T2DM are one of the more serious complications. Foot problems are the main source of suffering and costs for the patients and they also place a considerable financial burden on health care and on society in general. Strategies include prevention, patient education and close foot monitoring (Schaper et al., 2017).

T2DM Patients with peripheral neuropathy also have a history of foot ulceration or lower limb amputation, foot deformity, poor foot hygiene and inappropriate or inadequate footwear. Furthermore, routine inspections and checks of at-risk feet should be conducted at least once a year to identify those at risk of foot ulceration. Patients who have any of the risk factors must be examined more frequently. These include a history of ulcers, previous amputations, end-stage kidney disease, social isolation, access to poor health care, walking without using a pedestal and a regular foot examination concerning vascular status, skin, footwear and an assessment of neuropathy (S.A Bus, D.G. Armstrong, R.W. Van Deursen, J.E.A.Lewis, C.F Caravaggi, 2016).

Health education for patients about foot care is presented in a structured, organized and repeated manner, both verbally and through media channels. This plays an important role in preventing foot problems. Patients with T2DM must learn how to recognize potential foot problems and they must be aware of the steps that they must take when problems arise. One of the sports recommended for people with T2DM is foot exercises (Lincoln et al., 2008). Gymnastic foot stretches aim to smooth the blood circulation that is disrupted. This is because leg exercises can strengthen the leg muscles. This is in accordance with Mariana, et.al. (Souza et al., 2017), who stated that T2DM foot exercises aim to improve blood circulation so then the nutrients can get to the tissues smoother. It can also strengthen the small muscles, calf muscles and thigh muscles, and overcome the limitations of joint motion that often experienced by T2DM patients. This is supported by theories involving endoneuria blood flow, increased nitric oxide synthesis and increased $\mathrm{Na}+/ \mathrm{K}+-$ ATPase activity with given training efforts (Brand \& D, 2016).

Regular footwear, improper footwear and barefoot walking with insensitive feet are the main causes of foot ulceration. Patients with a loss of sensation should be taught about protection and the appropriate use of footwear so then the use of footwear at any time, both inside and outside the room, is paired with the identification of pre-ulcer signs in T2DM patients characterized by redness or pain (Schaper et al., 2017). The limitations in this study were that it was limited in terms of the time available and the intervention in the treatment group was for 3 weeks. Patient changes and any developments will be more visible if the intervention is carried out over a longer time period.

\section{CONCLUSION}

SGFDP explains the basic principles of preventing foot problems in patients in a manner that can be carried out in a session once a week and re-evaluated after 3 weeks by discussing, sharing knowledge and undergoing foot ulcer prevention simulation using foot exercise. Sharing information and the attention given by the nurses with regular meetings can increase patient knowledge and behavior changes in the T2DM patients to encourage them to take positive actions. This was proven to prevent foot injury in patients with T2 T2DM. SGFDP can be done regularly to train the T2DM type 2 patients to maintain a good lifestyle including good food, a balanced diet, exercise and regular activities. The next researchers could improve the treatment of SGFDP based on culture and by evaluating the qualitative results.

\section{CONFLICT OF INTEREST}

The authors have declared that they have no conflict of interest.

\section{ACKNOWLEDGEMENT}

This study was funded by Politeknik Kesehatan Kementrian Keseahatan Palembang. We would like to thank to Health Primary Care for permission and assistance and all respondents that cooperate to join the research.

\section{REFERENCES}

Albargawi, M., Snethen, J., Gannass, A. Al, \& Kelber, S. (2017). Relationship between person' s health beliefs and diabetes self-care management regimen. Journal of Vascular Nursing, 1-6. https://doi.org/10.1016/j.jvn.2017.07.002

Badan Penelitian dan Pengembangan Kesehatan. (2013). Riset Kesehatan Dasar (RISKESDAS) 2013. In Laporan Nasional 2013.

Bakar, A., Nursalam, Adriani, M., Kusnanto, Qomariah, S. N., Hidayati, L., Pratiwi, I., \& Ni'mah, L. (2017). Spiritualitas perawat Meningkatkan Perilaku Caring. International Journal of Evaluasi Dan Penelitian Dalam Pendidikan (IJERE), 6(April), 23-30.

Brand, S. L., \& D. (2016). Evaluation of the effect of nurse education on patient-reported foot checks and foot care behaviour of people with diabetes receiving haemodialysis. Diabetic Medicine, 33(2), 204-207. https://doi.org/10.1111/dme.12831

Chai, S., Yao, B., Xu, L., Wang, D., Sun, J., Yuan, N., Zhang, X., \& Ji, L. (2018). The effect of diabetes selfmanagement education on psychological status and blood glucose in newly diagnosed patients with diabetes type 2. Patient Education and Counseling, 101(8), 1427-1432. https://doi.org/10.1016/j.pec.2018.03.020

Fan, L. (2012). Examining the Feasibility , Acceptability and Effects of a Foot Self-Care Educational Intervention in Adult Patients with Diabetes at Low Risk for Foot Ulceration by. In 
ProQuest. University of Toronto.

Hsieh, Y. L., Lee, F. H., Chen, C. L., Chang, M. F., \& Han, P. H. (2016). Factors Influencing Intention to Receive Examination of Diabetes Complications. Asian Nursing Research, 10(4), 289-294. https://doi.org/10.1016/j.anr.2016.10.004

Iljaž, R., Brodnik, A., Zrimec, T., \& Cukjati, I. (2017). EHealthcare For Diabetes Mellitus Type 2 Patients - A Randomised Controlled Trial In Slovenia EZdravstvena Oskrba Bolnikov S Sladkorno Boleznijo Tipa Ii - Randomizirana Kontrolirana Raziskava V Sloveniji. 56(3), 150-157.

Jankowska-Polaska, B., Fal, A. M., Uchmanowicz, I., Sen, M., Polanski, J., \& Kurpas, D. (2015). Influence of organized diabetic education on self-control and quality of life of patients with type 2 diabetes. International Journal of Diabetes in Developing Countries, 35, 79-87. https://doi.org/10.1007/s13410-014-0253-4

Kusnanto. (2017). Asuhan Keperawatan pada Klien dengan Diabetes Mellitus Pendekatan Holistic Care. AUP.

Lincoln, N. ., Radford, K. ., Game, F. ., \& Jeffcoate, W. . (2008). Education for secondary prevention of foot ulcers in people with diabetes: A randomized controlled trial. Diabetologia, 51, 1954-1961.

Martis, R., Crowther, C. A., Shepherd, E., Alsweiler, J., Downie, M. R., \& Brown, J. (2018). Treatments for women with gestational diabetes mellitus: an overview of Cochrane systematic reviews. Cochrane Database of Systematic Reviews. https://doi.org/10.1002/14651858.CD012327.p ub2

Nursalam. (2016). Metodologi Penelitian Ilmu Keperawatan (4th ed.). Salemba Medika.

PERKENI. (2015). Pengolahan dan Pencegahan Diabetes Melitus Tipe 2 Di Indonesia 2015. https://doi.org/10.1017/CB09781107415324.0 04

Putri, D. S. R., Yudianto, K., \& Kurniawan, T. (2013). Perilaku Self-Management Pasien Diabetes Melitus ( DM ). 1(April 2013), 30-38. https://doi.org/10.24198/jkp.v1n1.4
Rachmawati, N., Safitri, N., K, D., Keperawatan, M. J., Kedokteran, F., \& Diponegoro, U. (2015). Gambaran Kontrol dan Kadar Gula Darah pada Pasien Diabetes Melitus di Poliklinik Penyakit Dalam RSJ Prof. Dr. Soerojo Magelang. 01, 1-8.

S.A Bus, D.G. Armstrong, R.W. Van Deursen, J.E.A.Lewis, C.F Caravaggi, P. R. C. (2016). IWGFD guidance on footwear and offloading interventions to prevent and heal foot ulcers in patients with diabetes. Diabetes/Metabolism Research and Reviews, 32(30), 13-23. https://doi.org/10.1002/dmrr

Schaper, N. C., Van Netten, J. J., Apelqvist, J., Lipsky, B. A., \& Bakker, K. (2017). Prevention and management of foot problems in diabetes: A Summary Guidance for Daily Practice 2015, based on the IWGDF guidance documents. Diabetes Research and Clinical Practice, 124, 84-92. https://doi.org/10.1016/j.diabres.2016.12.007

Shearman, C. P., \& Rawashdeh, M. (2016). Foot complications in patients with diabetes. Surgery (Oxford), 34(4), 192-197. https://doi.org/10.1016/j.mpsur.2010.02.002

Souza, A. L. R., Guimarães, R. A., de Araújo Vilela, D., de Assis, R. M., de Almeida Cavalcante Oliveira, L. M., Souza, M. R., Nogueira, D. J., \& Barbosa, M. A. (2017). Factors associated with the burden of family caregivers of patients with mental disorders: A cross-sectional study. BMC Psychiatry, 17(1), 1-10. https://doi.org/10.1186/s12888-017-1501-1

SPSS, I. (2019). IBM SPSS Statistics Vers 25. https://www.ibm.com/id-en/marketplace/spssstatistics/details

Waspadji, S. (2006). Komplikasi Kronik Diabetes: Mekanisme Terjadinya Diagnosis dan Strategi Pengelolaan. FK UI.

Wawan, A., \& Dewi, M. (2014). Teori dan Pengukuran Pengetahuan. Nuha Medika.

Yamin, A., Windani, C., \& Sari, M. (2018). Relationship of Family Support Towards Self-Management and Quality of Life of Patients with Type 2 Diabetes Mellitus. 6, 175-182. 